\title{
1. Recent development and inspirations of new legal realism
}

\section{Deng Jinting*}

\section{INTRODUCTION}

In the 1920s and 1930s, under the law and society theories of Roscoe Pound, Karl N. Llewellyn led the legal realism movement to resolve the chaos in common law rules after the abolition of the writ system and the judicial rigidity supported by formalism, and to meet the needs of governments' power expansions. These legal realists studied different objects and used different tools. But in terms of the objects they criticized, they have some common characteristics. First, they all objected to making legal rules the research focus, or excluding other elements that are not rules from legal studies through conceptualizing law. They promoted focusing study on facts, including the behaviors of the judiciary, concrete case facts and decisions. They thought that judgments are mainly influenced by facts, not legal rules; and that even those facts that have no legal importance may affect judicial decisions. Law's influence on judges exists but is subordinate. Second, they all objected to laws that are self-coherent and agreed that judgments should be predicted through legal reasoning. On one hand, legal rules and logical reasoning are insufficient to decide a unique reasonable result of a case. On the other hand, they cannot explain why the judge makes

* This chapter is the research result of the program 'Perfection on the Retrieval System of the Chinese Case - Based on the Comparative Study of America and China' (No. 2013030014) funded by Renmin University of China Science Study Fund (the Special Fund of Central University's Basic Science Research Fund). Thanks are due to the anonymous reviewers and the editor for their detailed amendments. All responsibilities for the contents belong to the author. 
such a decision. Finally, they all object to studying only the welltrodden precedents and carrying out unrealistic studies on abstract theories. They promote interdisciplinary and empirical research. ${ }^{1}$

After that period, legal realism reached its lowest point, appealing to the Nazi dictatorship for its critique of the rule of law, and the principal legal realists left the movement, while the law lost its uniqueness under too great an emphasis on policy's influence over law, and, more importantly, Herbert L.A. Hart countered the suspicion of law with strong arguments for rebuilding the concept of law. During its decline, Hart's Legal Process Theory arose. Facing the legal realists' strong proof on the uncertainty of law, legal process theorists could only admit it and then rebuild the faith in law, arguing that the rule of law is reliable through institutionalism, logical reasoning and expanding the concept of rule.

However, critical legal studies, arising in the 1970s and 1980s, brought the legal realists' opinions on the uncertainty of law back into the American jurisprudential mainstream. To support the claims that public organs shall intervene in private fields to protect weak parties' interests, critical legalists strengthened legal realism and proved the uncertainty of law to an extreme extent. ${ }^{2}$ These opinions were inherited by feminists and critical race theorists. In the meantime, law and economics gained momentum, which applied economics to analyzing and evaluating which legal rules are economically effective, or to predicting what legal rules shall be issued, accordingly. It is because legal realism proved that law was not self-consistent that law and economics could openly take the stage, and legalists and judges could publically discuss the influence of the social costs, benefits and efficiency of economic analysis in judicial decision-making. However, the development of law and economics is a double-edged sword in relation to legal realism. On the one hand, it provided tools to realize realism's attention on facts and the relation between law and society and proved that non-legal factors, such as social costs and benefits, affected judicial decision-making and were primary in some situations. On the other hand, it provided a logical reasoning route to regulate the selection of contradictive legal rules and interpretations, decreasing the uncertainty of law. Another theory closely related with legal realism, law and society, also developed after legal realism had broken the perfection of the rule of law. It further disclosed the gap between law and society, used multidisciplinary methods to capture and

1 Brian Leiter, 'American Legal Realism' in Martin P. Golding and William A. Edmundson (eds), The Blackwell Guide to the Philosophy of Law and Legal Theory (Oxford: Blackwell 2004) 33.

2 Ibid. 
analyze legal phenomena in society, disclosed the difference between law in books and law in action, and produced amounts of empirical research results after decades of development. Therefore, legal realism successfully broke the closed legal system established by the old legal formalism, making it open to politics, morality, economics and social sciences. But it did not carry out concrete quantitative and qualitative studies nor produce findings in the actual influencing of these factors. However, critical legal studies, law and society, law and economics and empirical legal studies enjoyed many achievements during decades of development.

In the beginning of the twenty-first century, with the previous theories and movement as the backdrop and founded on the development of interdisciplinary and empirical legal studies, Cass R. Sunstein, Stewart Macaulay and other scholars launched the new legal realism movement and called the previous one old legal realism. At this time legal realism has two meanings. First, it further breaks the self-consistency and certainty of the expanded rule system raised by the new legal formalism to cover the influence of non-legal factors. It emphasizes that some extralegal factors cannot be abstracted in rules, and holds that there are no universally applicable principles. Rules should be concrete and responsive to facts, rather than being general. From this perspective, the new legal realism argues that alternative dispute resolutions should be developed to answer the judicial insufficiency caused by the development of social pluralism. Second, it emphasizes the operation of building a legal rule system of results, especially empirical research results, from the theories and movements, such as law and economics and empirical legal studies, after the old legal realism. Concretely speaking, for one thing, it continues the groundbreaking work of the old legal realism, promotes grassroots and factual research, and calls the attention of legalists, including legal formalists, to the influence of extralegal factors over law and the qualitative and quantitative research on such influence. For another thing, it requires legalists, including legal formalists, to operationalize these results when studying legal phenomena and designing rules. The re-emphasis of legal realism is to build bridges between theoretical legal studies and research on extralegal factors. Many new legal realists are also representative scholars in critical legal studies, law and society, law and economics, etc. They re-uphold the flag of legal realism, seeking to expand the influence of relevant research and guide further study. Therefore, one aspect of the new legal realism's development is reflected in guiding those legal movements, changing their methodologies and operationalizing their results. The development discussed in this chapter thus includes the results from other legal movements that relate to open and factual studies and their variations caused 
by the new legal realism. Another aspect of the new legal realism's contribution is its development of the old one's guiding principles, making them more neutral, objective, open and factual.

Concretely speaking, the new legal realism inherits the core values of the old one in objecting to focusing research on legal rules, or considering them as self-consistent and certain in nature, or applying formalistic and dogmatic methodologies, while promoting bottom-up empirical research and using other disciplinary methods to study law. ${ }^{3}$ But, in reality, the degrees of the new and legal realisms are different. The new one emphasizes research into more basic-level legal behaviors, including district court judgments and the general public's legal opinions; is more cautious when talking about the policy's influence over law to prevent confusing law and politics and eliminating the law's uniqueness; tries to avoid non-neutral non-objective research; carries out an amount of empirical legal studies; and constantly amends specific research methods and in practical terms brings into legal studies other disciplinary tools. Thus, the new legal realism operates on a more basic level and is closer to social reality than the old one. The old legal realism only proved that there was a big gap between legal rules and society, but it could not explain what factors and conditions contribute to this gap and what the underlying rules are. Lacking the development of other disciplines, the old legal realists could only analyze the gap by guesswork and reasoning, and still achieve unrealistic conclusions - being either too dependent upon psychology and intuition, or sunk in the deficiency of abstract concepts by categorizing facts. The new legal realists benefit from the development of law and economics and law and society, and in practical terms could handle the complicated and numerous data at the surface level of society, disclosing the existing status and underlying reasons for the gap between legal rules and society through facts and phenomena.

Previous literature in China frequently discusses the old legal realism. The research on the new one is limited to a preliminary introduction of its background, reasons and principles. ${ }^{4}$ However, after ten years'

3 Frank B. Cross, 'Political Science and the New Legal Realism: A Case of Unfortunate Interdisciplinary Ignorance', Northwestern University Law Review (Vol. 92, No. 1, 1997) 251; Stewart Macaulay, 'The New Versus the Old Legal Realism: Things Ain't What They Used to Be', Wisconsin Law Review (Vol. 2, No. 2, 2005) 365 .

4 The main Chinese theses and Chinese translated theses that specifically discuss the old legal realism include: Qiu Shaoji, 'Rebirth of Legal Realism Comment on Blaine Wright's Naturalism Legal Ideas', Tsinghua University Legal Review (Vol. 1, No. 1, Tsinghua University Press, 2006) 179, 196; Sun 
development, the new legal realism has used empirical and interdisciplinary methods to study social-legal phenomena, abstracted theoretically reliable explanations and raised many problems worthy of attention. This chapter further summarizes the recent development and results of the new legal realism. Although some parts relate to the results of other legal theories or movements, this chapter analyzes them from the legal realistic perspective.

First, this chapter compares the old and the new legal realisms from a holistic perspective. Part 2 consists of four points. The first two points discuss the difference between the old and the new legal realisms in conceptualizing law and focusing on facts other than rules. The remaining points introduce the development in methodologies of the new legal realism. Parts 3 and 4 analyze in detail the improvement in interdisciplinary and empirical legal study methodologies of the new legal realism. Certainly, when talking about achievements, criticisms shall also be raised in order to comprehensively understand both its good and bad aspects. Thus, Part 5 centers on the criticism, disputes and responses to

Qidong and Fan Jinxue, 'Comments on Frank's Legal Realism', Shandong Law and Society (No. 3, 2007) 95, 99; Xu Qingkun, 'Reread American Legal Realism', The Study of Comparative Law (No. 4, 2007) 1, 13; Yu Xiaoyi 'The Investigation of the Fundamental Appeal of Frank's Legal Realism Ideas', PhD thesis, Jilin University, 2007; Liu Zhong, 'The Criticism and Construction of Legal Realism', Legal Science (No. 5, 2009) 13, 21; Lu Yufeng, 'American Legal Realism: The Contents, the Rise and Fall and its Effects', Tsinghua Law (No. 6, 2010) 85, 97; Ding Xiaodong, 'The Review of Legal Realism - a Study of Knowledge', Journal of Kunming University of Science and Technology (Social Science Edition) (No. 4, 2010) 15, 23; Zhang Juan, 'What is the Legal Realism - the Debate of Pound, Llewellyn, Frank', Journal of Southwest University of Political Science and Law (No. 5, 2010) 3, 13; Hu Ming, 'Legal Realism and Transitional Society's Criminal Justice', Legal Research (No. 2, 2011) 52, 69; Xue Wanbao, 'The Interpretation of Llewellyn's Legal Realism, The Private Law (Vol. 1, No. 9, Central China Science and Technology Press, 2011) 255, 277; Yu Xiaoyi, 'The Skeptical Approach of the Legal Realism', Journal of South China University of Technology (Social Science Edition) (No. 5, 2011) 57, 61; [Germany] Kang Tero Horowitz, 'Rationalist Criticism of American Legal Realism', The Legal Method (Qing Ling tr, Vol. 12, Shandong People Press, 2012 edn) 66, 75. For a general introduction to the new legal realism: see Fan Yu, 'The Boom of the New Legal Realism and the Criticism of the Contemporary Chinese Law', China Legal Science (No. 4, 2006) 38, 51; [America] Stewart McCauley, 'The New Versus the Old Legal Realism: "Things Ain't What They Used to Be", Political and Legal Tribune (Fan Yu tr, No. 4, 2006) 54, 74; Yu Xiaoyi and Li Lianying, 'Comments on the Movements of the New Legal Realism', Citizen and Law (Law Edition) (No. 9, 2011) 19, 21. 
the opinions and methodologies of the new legal realism. Considering that China's interdisciplinary and empirical legal studies are still at an elementary stage, it is important to learn from these developments to help studies on the existing status of the rule of law and the gap between law and society. Thus, the last part addresses ways that the new legal realism has inspired China's legal studies.

\section{THE DEVELOPMENT OF THE NEW LEGAL REALISM'S MAIN OPINIONS}

It has been ten years since the concept of 'new legal realism' was first introduced in a conference held in America in 2004. In 2012, the first European New Legal Realism Conference was held in Copenhagen. However, as a legal movement, the new legal realism is still at an elementary stage and has not achieved the influence of the old one. Moreover, when the old legal realism was born, the law and economics, law and society, etc. fields were not yet developed. The old legal realism targeted the mechanical judiciary and closed legal governance promoted by the mainstream legal formalism. Currently, with law and economics, law and society, etc. having been widely accepted, the new legal realism has appeared as a bridge. Its role changed from front- to backstage. Thus, it is impossible and unnecessary for it to be as popular as the old legal realism.

That said, the new legal realism has been influential in Europe. First, it changes the legal methodologies there. Its promotion of applying economics, politics, anthropology and sociology in legal studies, rather than using a single traditional legal method, have led to renewed discussions on whether law is a science. ${ }^{5}$ Some scholars further study how to improve the legal education and professional code to promote the changes from single method to multidisciplinary methodologies and from domestic to multi-state legal studies, to meet the needs in the integration of Europe and globalization. ${ }^{6}$ The criticisms of traditional theoretical legal study methodologies are relatively weak throughout Europe; such discussions appear in several European countries including the UK,

5 H. Hans-Eberhand, 'Ist "Rechtswissenschaft" eine Wissenschaft?', Rechtstheorie (Vol. 34, No. 2, 2003) PL 229, 244.

6 R.V. Gestel, H.W. Micklitz, and M.P. Maduro, 'Methodology in the New Legal World' (May 1, 2012), EUI Working Papers Law, 2012(13) http://ssrn.com/ abstract=2069872 (accessed 27 March 2014). 
Belgium and Holland. ${ }^{7}$ Second, empirical legal studies has become more and more popular. In the past twenty years, great interest in empirical legal studies has appeared in many European countries, including the UK, Holland, Belgium, Germany and Spain, although not in the mainstream. ${ }^{8}$

That said, the new legal realism is mainly led by American scholars. The following sections explain the recent developments in American academia.

\subsection{Findings on the Influence of Legal and Extralegal Factors over Judicial Decision-making}

The new legal realism holds a balanced opinion on this issue. ${ }^{9}$ Its proponents admit that sometimes law is inconsistent, judges may be selective in their decision-making, they can manipulate law and logic, and they can be influenced by extralegal factors, including politics, morality and personal bias. But they also believe that the legal system still functions, that judges are often bound by law and logic, and that judicial decisions are generally predictable. ${ }^{10}$ Guided by these opinions, they further study more concrete problems, including: what specific legal and extralegal factors have practically influenced judicial decisionmaking; in what situations and how frequently would judges make decisions without restrictions from law and logic; and what are the different influencing institutions of the legal and extralegal factors over the judiciary. ${ }^{11}$ Therefore, although new legal realists do not believe in the rule of law myth, they do not relinquish the values of law - they still think law has its own unique value and wish to disclose more completely the actual functioning status of the legal system, especially from its interaction with other social systems.

\footnotetext{
Ibid., pp. 14, 15, footnotes 59, 61.

8 P. Cane and H. Kritzer (eds), The Oxford Handbook of Empirical Legal Research (New York: Oxford University Press, 2010) 2.

9 B. Leiter, 'Legal Formalism and Legal Realism: What Is the Issue?', Legal Theory (Vol. 16, Issue 29, 2010) 123; B.Z. Tamanaha, 'Balanced Realism on Judging', Valparaiso University Law Review (Vol. 44, Issue 4, 2010) 1243.

10 Ibid., B.Z. Tamanaha, p. 6, and B. Leiter, p. 23.

11 Supra note 9, B. Leiter, p. 123.
} 


\subsection{How to Study Judicial Behavior by a Bottom-Up Method}

Along with the development of social science and computer science and the appearance of large empirical legal studies, legalists realize that judges do not decide cases mechanically according to the law and that at least in some cases they are influenced by their political positions. ${ }^{12}$

Until now, the new legal realists have reflected on the previous research and realized the limits therein. These include: previous realistic research targets on published appellate decisions in some legal fields thus may not be representative; previous research only cares about limited extralegal factors, ignoring some other important factors, such as sex and race; previous research simply uses the votes of judges to measure whether the judges are influenced by political opinions, without considering other possible measures, such as the involved concrete legal rules and the effects of precedents. ${ }^{13}$

To overcome these limitations, new legal realists propose that when studying judicial behaviors, the following three points should be noted. First, expand the cases studied to include more 'bottom' cases from more legal fields. Second, analyze the influence of more factors over the judiciary than the political position, but also include sex, race, legal rules, precedents and judicial institutional strategies. Third, emphasize the 'up' part of the 'bottom-up' research, trying to operationalize and theorize empirical results, and increase the evaluating measures, such as the effects of cited precedents, legal rules and logic, contributing to the prediction of judicial behaviors. ${ }^{14}$

In addition, some new legal realists think that the empirical results on the influence of extralegal factors over the judiciary can increase judicial self-awareness, making it easier to avoid such influence and maintaining judicial objectivity and neutrality. ${ }^{15}$

12 S.J. Ware, 'Originalism, Balanced Legal Realism and Judicial Selection: A Case Study' (August 3, 2012) 16, 17, http://papers.ssrn.com/sol3/papers.cfm? abstract_id=2129265 (accessed 27 March 2014).

13 M. Heise, 'The Past, Present, and Future of Empirical Legal Scholarship: Judicial Decision Making and the New Empiricism', University of Illinois Law Review (No. 4, 2002) 843, 848.

14 E. Braman and M. Pickerill, 'Path Dependence in Studies of Legal Decision Making', pp. 9, 18, paper presented at the 'What's Law Got to Do to With It?' Conference, Maurer Law School, Indiana University (March 27 and 28, 2009).

15 Supra note 13, p. 804. 


\subsection{On the Empirical Study Methodology}

New legal realists insist on using empirical study as the basic methodology, emphasizing not only bottom-up research but also the theoretical operation of these results, and advocating multidisciplinary study. They also admit the limits of empirical study and call for critical reflection on such study. The obstructions to carrying out empirical legal studies become less as more data are published, more diversified databases, especially multi-user databases, are established, ${ }^{16}$ more scholars of interdisciplinary background appear, and law schools hold more educational programs and training courses on empirical study techniques. Thus, empirical legal studies are enjoying a huge growth and their use is not limited to the new legal realists. ${ }^{17}$

During the development of the field, new legal realists constantly reflect on such studies and consider how to improve them to better analyze law in action. On the one hand, they object to those empirical studies done without considering meanings and realistic needs and emphasize the theoretical operationalization of the empirical results. On the other hand, they object to the non-neutral, biased empirical research purposely used to prove certain existing theories. They also object to isolated empirical studies on extralegal factors and promote combining them with studies on legal factors, such as legal texts and rules, and the results from the formalistic 'top-down' research, that is, theoretical reasoning research. ${ }^{18}$ Moreover, they realize the limits of empirical studies. Especially because any single empirical method can be deficient in data collection, research design, or data analysis, its results can hardly be considered general, comparable and reliable. Thus, new legal realists recommend the combining multiple empirical methods when doing empirical studies, rather than depending upon only quantitative or qualitative or other single methods. ${ }^{19}$

\subsection{On Interdisciplinary Research}

In studying law, new legal realists emphasize factual and open-minded research, apply multidisciplinary theories and methods, and utilize all possible scientific methods beneficial for understanding law in action and

16 'Multi-user Database' is the database that allows multiple users access and use at the same time to share resources. Supra note 13, pp. 830, 831.

17 Supra note 13, pp. 826, 832.

18 Supra note 14.

19 Supra note 13. 
its functioning effects, so that legal studies can neutrally, objectively and comprehensively reflect law in reality. Until now, new legal realists have been gradually realizing the difficulty in combing multiple disciplines. Without knowing the pros and cons of different disciplinary methods, combining them may not produce more beneficial research. Worse, it may have adverse effects. ${ }^{20}$ There are two ways to proceed with multidisciplinary research. First, the multidisciplinary method could be used to provide diversified perspectives when studying one object. Second, some results in other disciplines may directly contribute to legal studies and thus will be translated into legal fields. ${ }^{21}$

New legal realists emphasize that when combining multiple disciplines it is important to 'translate' the results of different disciplines and build communication bridges, so that such results can be understood and utilized by scholars in different disciplines. ${ }^{22}$ Also, when emphasizing the importance of combining with other disciplines, the uniqueness of law should not be relinquished, the values of traditional legal study methods should not be condemned, and the mistakes of reductionism and scientism, such as considering law to have no unique value distinct from politics and thus viewing it as a branch of politics, or holding the scientific method to be a truism and denying its limits, should be avoided. ${ }^{23}$ Finally, the purpose of disclosing the reality of the law as far as possible should be constantly adhered to, the diversification of methods in research should be tolerated, the bias towards the combination of only certain or some disciplines should be rejected, and the appearance of narrower legal schools which only respect their own methods and thus obstruct smooth communications between themselves and other disciplines, should be avoided. ${ }^{24}$

20 Thomas J. Miles and Cass R. Sunstein, 'The New Legal Realism', The University of Chicago Law Review (Vol. 75, No. 2, 2008) 831, 835; Victoria Nourse and Gregory Shaffer, 'Varieties of New Legal Realism: Can a New World Order Prompt a New Legal Theory?', Cornell Law Review (Vol. 95, Issue 1, 2005) $115,127$.

21 Ibid., Thomas J. Miles and Cass R. Sunstein, p. 833.

22 Supra note 14, p. 7.

23 Supra note 20, Victoria Nourse and Gregory Shaffer, pp. 115, 118.

24 Michael McCann, 'Dr. Stranglelove (or: How I Learned to Stop Worrying and Love Methodology)', Law and Society Reconsidered (Special Issue: Studies in Law, Politics, and Society) (Vol. 41, 2007) 21, 40-46. 


\section{THE RECENT DEVELOPMENT OF INTERDISCIPLINARY RESEARCH IN THE NEW LEGAL REALISM}

The new legal realism promotes the integration of multiple disciplines and the application of interdisciplinary methods in legal studies. The theories and methods of other disciplines, such as sociology, politics, anthropology, behavioral science, psychology, economics, statistics and institutionalism, have been brought into legal studies. Due to limitations of space, the following section only discusses two of the most frequently used and successful of the available interdisciplinary research methods.

\subsection{The Combination of Politics and Law in Studying Judicial Behaviors}

As a branch of politics, legal politics has actually studied the relation between politics and law for a long time and provided many empirical results on the influence of ideology on judicial behavior. Consequently, an important opinion of the new legal realism is that judicial behaviors are affected by the judges' 'personalities'. New legal realists wish to quantify such influence and prove what factors are involved and how they would influence judicial behavior through empirical research on a large sample of case facts and decisions. As mentioned by Llewellyn, the uncertainty of law lay in the fact that the personality of the judge could explain the judgments to some extent. ${ }^{25}$ Since ideology has been considered as an important 'personality' factor that could affect judicial behavior, many legalists have become interested in the research of legal politics and brought into legal studies their methods and models, forming the 'Attitudinal Model' within the new legal realists' research methodology. The Attitudinal Model is a behavioral research method to study the reflection of ideology in legal and judicial behavior and to analyze the influence of judges' rational and irrational presumptions. ${ }^{26}$ It comes from politics and holds that law cannot completely restrict judicial behavior, and that the ideology and political party of the judges will influence or

25 Karl N. Llewellyn, 'Some Realism about Realism: Responding to Dean Pound', Harvard Law Review (Vol. 44, No. 8, 1931) 1242.

26 Another common behavior study approach is to introduce behavioral economics to legal study, which is sometimes called the 'Behavioral Model'. See D.A. Farber, 'Toward a New Legal Realism: Reviewing Behavioral Law and Economics (Cass R. Sunstein, ed., 2000)', University of Chicago Law Review (Vol. 68, No. 1, 2001) 279. 
even determine their judgments. It consists of several steps. First, a measurable presumption from this opinion is that if such influence exists, it will be reflected in concrete judgments. For example, judges of the Democratic Party will support a more liberal interpretation of the law. Second, several measurable indicators of the ideology (such as what kinds of interpretations of law are liberal or conservative) shall be decided. Then, quantitative or qualitative analyses of the correlation between these measurable indicators and the facts and decisions of certain cases shall be carried out to test the validity of the previous presumption, and to see whether and to what extent the judges are influenced by ideological factors. The Attitudinal Model was first applied in wide-scale quantitative research on administrative appellate judgments. ${ }^{27}$ Since then, many research findings have established different models, substituting ideological factors with religion, political party, immigration and policy considerations, and tested them, proving to some degree that these factors could also influence judicial decisions. ${ }^{28}$ Sunstein et al. further prove 'Panel Effects' in appellate judicial decisions. That is, as the numbers of Democratic judges increase, the opinions of the Democratic judges become more liberal; and as the numbers of Republican judges increase, the opinions of the Democratic judges become more conservative. Similar findings exist in Republican judges. ${ }^{29}$

As the research using Attitudinal Model increases, the new legal realists constantly reflect on the limits of this model and make improvements. Some of the limits come from data collection, some regard concept and conceptualization, and some relate to normative meanings of the results.

On data collection, research using the Attitudinal Model only covers published appellate opinions in some legal fields, and thus it is difficult to reach general conclusions. Because different states apply different appellate standards, the research of some states is hardly comparable with other states. Moreover, the unpublished opinions should also be covered, as in these cases are subject to less public attention and precedential influence and thus can show more clearly the effect of ideological factors. ${ }^{30}$

On concept and conceptualization, research using the Attitudinal Model only cares about some ideological factors (such as political party,

27 R.L. Revesz, 'Environmental Regulation, Ideology, and the D.C. Circuit', Virginia Law Review (Vol. 83, No. 8, 1997) 8.

28 Supra note 20, Victoria Nourse and Gregory Shaffer, p. 78, footnote 57.

29 Supra note 20, Thomas J. Miles and Cass R. Sunstein, p. 838.

30 Ibid., pp. 841,842 . 
nominating president, conservative/liberal, etc.) while ignoring other important personal factors (such as race, sex, educational background, working experience, etc.). ${ }^{31}$ When measuring the influence over judicial behavior of ideology, it uses the votes of the judge as the only indicator (i.e. in a certain case whether the judge votes for or against the claim) and does not consider other factors to determine the judge's attitude, even if the facts and involved laws are very different between the cases. ${ }^{32}$ The judge's vote is important, but it cannot be the sole indicator. Sometimes, the judge may support the claim because of the special circumstances of the case or the strong binding effects of the rules or precedents, not because the judge is conservative or liberal, or because the judge is influenced by an ideology. Many other indicators should be considered when testing the hypothesis. An important one to consider is the binding effects of precedents or legal rules, which improves the Attitudinal Model by incorporating the legal model. ${ }^{33}$ The legal model emphasizes that when studying ideological influence over judicial behaviors, factors including precedents, legal rules and legal texts should also be considered, so as to indicate when these legal factors could not bind the judges and what interaction there is between them and ideological factors. ${ }^{34}$

On the normative meanings, research using the Attitudinal Model only stops at the analysis of the collected data and makes conclusions like this: from the collected data, we can see that in some cases, when the majority of judges are liberal, the originally conservative judge will become more liberal. However, without the theoretical operation of such a result or understanding its normative meaning, it remains unclear why this phenomenon exists, what the underlying reason is, whether all levels of courts have such a result, how big the panel effect would be and how it would interact with the effects of legal factors. Thus, the judge's judicial behavior is still unpredictable. ${ }^{35}$ With a lack of theoretical analysis, it is difficult to apply the Attitudinal Model into the legal studies in other countries. For example, could it be applicable in statutory countries? To answer this question, it is necessary to analyze the theoretical presumptions behind the model. A main condition for the application of the Attitudinal Model is that it presumes that the judgments required by ideological factors or legal factors are different and

\footnotetext{
31 Ibid.

32 Supra note 14 , pp. 11, 13.

33 Supra note 14 , pp. $14,15$.

34 Supra note 13 , pp. 839, 840; note 12 , pp. 14, 15.

35 Supra note 20, Thomas J. Miles and Cass R. Sunstein, pp. 842, 844; note 13 , p. 838.
} 
that such differences are serious or disallowed in that country's legal system. For example, in America it is inconsistent with the democratic requirement if the judge decides cases according to ideology rather than law. But this concern does not exist worldwide. Without such understanding, the model may be wrongfully applied. Currently, some scholars have noticed the limits of the Attitudinal Model. ${ }^{36}$

\subsection{The Combination of Institutionalism and Legal Studies}

Institutionalism ${ }^{37}$ exists in sociology, economics and politics, and has some differences in each context. Generally speaking, it refers to the institutional role in the realization of any social value and goal, and thus studying their realizations should proceed against the relevant institutional background. The selection of different institutions can affect the actual implementation of the policy or law.

To bring institutionalism into legal studies means that the institutions, such as legislature, judiciary, administration, market, company, etc., will affect the actual function of the law, and may change the original purpose of the law, and that it is necessary to consider the influence of institutions when studying the law in society or economics. ${ }^{38}$ This has descriptive and normative meanings. The descriptive meaning is to observe how different individuals work in the institutions from a micro perspective, how they influence each other, how they practice rule and command, how a legal rule is transmitted, understood and changed in the institution, and how individuals change their behaviors as an institutional strategy, so as to predict the institutional influence over similar legal rules or policies in the future. The observer may even participate in the institution directly to better understand these influences and interactions. For example, when studying judicial behaviors, some scholars have applied institutionalism to analyze the strategic behavior of the judges in protecting judicial authority when deciding cases (for example, considering that the American Congress can overturn unconstitutional judgments by passing an act,

\footnotetext{
36 D. Robertson, 'Appellate Courts', supra note 8, pp. 572, 573.

37 The meaning of 'institution' in institutionalism includes both the meaning of regulation, norm, rule and the meaning of organization, i.e. the corporation and organization established according to some rules.

38 H. Gillman, 'The New Institutionalism, Part 1: More and Less than Strategy: Some Advantages to Interpretive Institutionalism in the Analysis of Judicial Politics', Law \& Courts (Vol. 7, No. 1, 1997) 6.
} 
the judges are more cautious when making decisions inimical to Congress). ${ }^{39}$ The normative meaning is to evaluate such institutional influence and interaction and consider whether it is beneficial for the realization of the legal value or policy, whether it is good for the development of the institution, and how the social and economic development will be affected. The institutionalism is further divided as it develops. Currently, there are comparative institutional analyses, micro analyses of institutions, recursive institutional analyses and new institutionalism. ${ }^{40}$ Among them, the type promoted by N. Komesar - comparative institutional analysis - is more popular. It means that any realization of substantive policy or legal purpose is influenced by the functions of the institutions that participate in its realization, and thus it is important to observe all these different institutions and then compare the influence and function of different institutions to evaluate them. For example, when worrying that the realization of legal purpose may be influenced by the judges' bias in the judicial institution, it is necessary to consider whether the legislation is even more likely to be influenced by an interest group obstructing the realization of law; and where there is concern that legislation may protect the interest group and infringe the ordinary people's interests, it is important to also analyze whether the market is more biased and weaker in protecting the weak party. ${ }^{41}$ Such a method promotes the comparative analysis of the influences by different institutions over the realization of the purpose, provides information for the selection of institutions, and objects to studying in isolation the ability to realize a certain value or goal of a certain institution. Komesar argues that without comparison it is impossible to understand the strengths and weaknesses of an institution in realizing the same rule or policy. ${ }^{42}$

As it is developed, so the comparative institutionalism method also improves. Previously, it placed too great an emphasis on individual

39 Supra note 20, Thomas J. Miles and Cass R. Sunstein, pp. 842, 844; note 13, p. 833.

40 T.C. Halliday and B.G. Carruthers, 'The Recursivity of Law: Global Norm Making and National Lawmaking in The Globalization of Corporate Insolvency Regimes', American Journal of Sociology (Vol. 112, No. 4, 2007) 1135; supra note 20, Victoria Nourse and Gregory Shaffer, pp. 85-87.

41 See G. Shaffer, 'Comparative Institutional Analysis and a New Legal Realism', Wisconsin Law Review (Vol. 2013, No. 2 2013) 609, 610.

42 N. Komesar, 'The Essence of Economics: Law, Participation and Institutional Choice (Two Ways)', in S.S. Batie and N. Mercuro (eds), Alternative Institutional Structures: Evolution and Impact (Hoboken: Taylor \& Francis 2008) 165. 
participation and interaction in understanding the influence of the institution over the realization of policy or legal purpose, while overlooking the influence of the institution as a whole. The culture and aim of the institution, the language of the institution, the behavioral style of the institution and the idea of the institution also affect the receiving and transmitting of the policy or law and have their own characteristics. ${ }^{43}$ To make up for this deficiency, some scholars include the perspective on the whole institution to observe how the institution itself interacts with other institutions. Previously, when comparing the influence of different institutions, the research was usually static to observe the different institutional influences on the realization of similar policies or laws, and then to compare and evaluate them. Such a method ignores the interaction between the institutions. In reality, there are normally multiple institutions participating in the realization of a policy, including the judiciary, administration, market and other social organizations. Their relations are not static but interactive. They affect each other. Thus, it is important to study dynamically the relation between institutions. They can also influence the legislation and administration, affecting the generation of the policy or law. Each institution also interacts with its own individuals. These factors all need to be attended to; ${ }^{44}$ they form the key points of recursive institutional analysis. ${ }^{45}$

Institutionalism has also been applied in international legal studies to understanding the difference between the actual results and the expectations, or between the actual results in different societies of the same international law or policy after being filtered by the institutions of different countries or areas. It is helpful for making predictions. It is also useful for understanding different opinions and their formation and the motivations of different countries over the same international problem or phenomenon. For example, in the environmental context, developed countries usually explain their opinions from the protective perspective, while developing countries start from the development perspective. ${ }^{46}$

\footnotetext{
43 Supra note 41, pp. 616, 617.

44 Supra note 41, p. 618.

45 Supra note 40, T.C. Halliday and B.G. Carruthers, p. 1135.

46 Supra note 41, pp. 626-628; G. Shaffer, 'A New Legal Realism: Method in International Economic Law Scholarship', in C.B. Picker, I. Bunn and D. Arner (eds), International Economic Law: The State and Future of the Discipline (Oxford and Portland, OR: Hart Publishing, 2008) 9, 10.
} 


\section{THE DEVELOPMENT OF EMPIRICAL LEGAL STUDIES}

Although the new legal realists promote empirical legal studies (ELS), they are not the only ones doing this. Such studies have wide applications in law and sociology, law and economics, law and politics, etc. ELS were very popular around the 1920s and 1930s, then declined for a while before making a comeback at the beginning of this century. ${ }^{47}$ Most early ELS scholars were connected with the old legal realism. ${ }^{48}$ As explained by $\mathrm{T}$. Eisenberg in one of his articles, the relation between the ELS and the legal realism movement was very complicated. The legal realists' ambition in ELS was largely not realized, but worked out by the later legal theories such as law and sociology and law and economics. Now ELS are again being promoted by the new legal realists. ${ }^{49}$ Eisenberg further pointed out that ELS are not a legal theory but a method. It provides a research route and method to analyze the law and legal phenomena in society. It is empirical not abstractive. Thus, it could be widely used to reflect the objective status of law in society and test theoretical hypotheses. It is not a competitor to other legal theories but a tool to help them do research and participate in the wide movement in probability legal studies. ${ }^{50}$

Currently the main fields of ELS include: research on the actual situation of law in society, such as how the law is produced, how it is understood and changed by social participants, how it changes their behaviors and expectations, etc.; research on the function of law, such as whether the law has unique functions, whether it has advantages over other dispute resolution methods, etc.; and research on the legal consciousness, such as how much legal knowledge an ordinary person has, whether they would use law to protect their own rights, how they perceive the meanings of law, etc. ${ }^{51}$ Some scholars argue that ELS could also be applied in jurisprudence and policy-making. ${ }^{52}$ ELS have many

\footnotetext{
47 Supra note 13, pp. 822, 824.

48 H.M. Kritzer, 'The (Nearly) Forgotten Early Empirical Legal Research', supra note 8 , p. 875 .

49 T. Eisenberg, 'The Origins, Nature, and Promise of Empirical Legal Studies and a Response to Concerns', University of Illinois Law Review (Vol. 2011, No. 5, 2011) 1720.

50 Supra note 49, p. 1719.

51 D.J. Galligan, 'Legal Theory and Empirical Legal Research', supra note 8, pp. 982, 984.

52 Supra note 51, pp. 991, 999.
} 
concrete research models and methods. Generally speaking, it first provides a hypothetical answer to a certain theoretical problem, analyzes the actual data through scientific methods, and then tests whether the hypothesis stands. It has four steps: designing research, collecting data, analyzing data and making conclusions. ELS methods that are frequently seen are: quantitative, qualitative and multi-method approaches.

\subsection{Quantitative Approach}

A main approach in ELS is quantitative methodology, which uses statistical methods to analyze collected data quantitatively to test a theoretical hypothesis. The hypothesis could be a general theoretical question, such as whether people would always behave rationally, or some specific problem, such as whether education is related to the commission of rape. The quantitative approach usually resolves questions of overall distribution and general trends, and how frequently a certain situation happens, such as how often people behave irrationally and how many rapists attain an educational level lower than middle school. It cannot answer questions of what and why, such as what extralegal factors influence judicial behavior and why they can have such influence. ${ }^{53}$ Quantitative ELS are carried out according to the above four steps. Each of them has its own characteristics. As quantitative research needs statistical techniques, legal scholars usually cooperate with statistics scholars. The designing research step decides whether the result would have substantive legal meanings, whether it could be operationalized to inspire or test legal studies and whether it would be persuasive to legal scholars. This step is very important and is where the legal scholars could contribute in the cooperative research. However, due to space limitations, this chapter only discusses the first step. However, all the four steps are important for the success of quantitative ELS.

When designing research, it is important to connect the theory with the reality. First, decide on the problem to be studied, such as whether the judges are affected by extralegal factors. Second, provide a hypothetical answer to it, such as 'because the legal rules cannot always give an exclusive conclusion, judges will be affected by extralegal factors when making a selection of the multiple conclusions'. Third, operationalize the hypothesis; for instance, if the judges are influenced by extralegal factors, their decisions will differ much in similar cases. Fourth, decide on the

53 L.B. Nielsen, 'The Need for Multi-Method Approaches in Empirical Legal Research', supra note 8, p. 953. 
measuring indicators, for example looking at what indicators control similar cases and what indicate different conclusions. ${ }^{54}$ At this point the designing step is completed. It is essential for the success of the quantitative research as the design of the research decides how the data will be collected and whether the conclusion will be reliable. To do the design well, two steps are important. The first is conceptualization, which is to consider what concept could well capture the particular problem or phenomenon studied, whether the constructed concept has different meanings in different disciplines or areas, whether it has several divisions, whether the concepts or divisions are causally related, etc. ${ }^{55}$ In this case, for example, one could consider whether the concerned question is 'would judges be affected by extralegal factors', or 'how would extralegal factors affect judges', or 'what extralegal factors that would affect judicial justice are worthy of research', etc. The second step is to shorten the distance between the operationalized hypothesis and the theoretical hypothesis when doing the operationalization. For example, consider whether or not 'judges make different judgments in similar cases' would prove that 'judges have been affected by extralegal factors', rather than 'such difference is due to the different understandings of the judges over legal rules'. These two processes influence the persuasiveness and reliability of the research conclusions. They are also the reasons why many legal scholars question the meanings of the quantitative ELS. ${ }^{56}$

\subsection{Qualitative Approach}

The qualitative approach is another important method in ELS. Its main methods involve reading (for example documents or materials such as judgments or newspaper articles) and communication (interacting with the researched objects through methods such as interviews, case studies and observation). ${ }^{57}$ The qualitative approach studies questions such as whether a phenomenon exists, what is the reason for its existence, how to categorize certain situations, and how they are related, but not questions of frequency or general distribution. It cannot give general conclusions,

\footnotetext{
54 L. Epstein and A.D. Martini, 'Quantitative Approaches to Empirical Legal Research', supra note 8, pp. 905, 908.

55 G. Goertz and A.G. Mazur, 'Mapping Gender and Politics Concepts: Ten Guidelines', in G. Goertz and A.G. Mazur (eds), Politics, Gender and Concepts: Theory and Methodology (New York: Cambridge University Press, 2008) 15.

56 Supra note 46, G. Shaffer, p. 5.

57 Guo Xinghua (ed.), Legal Sociology Course (Renmin University of China Press, 2011) 124, 150.
} 
but only conclusions on the samples. Differing from static quantitative research, a qualitative approach could more closely observe the legal phenomena in society and dynamically analyze the interaction between different objects.

Similar to quantitative research, the qualitative approach generally consists of four steps. First, when designing the research it is necessary to decide which qualitative method will better disclose interesting information according to the characteristics of the studied question, the availability of the materials, and the possibility of carrying out the research. Then consider how to realize such research. For example, if planning to do interviews, then the design of interview outlines and the selection of interviewees are important; if direct observation is applied, then the objects, the perspectives and angles, place, time and content of the observation needs to be decided. When designing qualitative research, it is important to hold an open, flexible and responsive attitude and be prepared to constantly adjust the original plan according to the actual situation, gradually unfolding the research and adapting to the changing conditions. First, it is important to select different qualitative methods to meet different demands. Second, when communicating, the interviews should be constantly adjusted and unfolded gradually around the whole theme. In addition, qualitative research does not require random samples, as it does not use statistical models and does not make overall predictions. To make the research more targeted, qualitative research usually selects purposive samples to do in-depth analysis, which are typical or special and are selected purposively. ${ }^{58}$ Although its conclusions are not generally applicable, if the design is good and the samples are selected well, such research could reflect the variation, scope and span of the phenomenon very well. Thus, when selecting samples, it is important to consider how to avoid researcher's bias, and how to increase their validity and reliability. ${ }^{59}$ Validity means whether the sample is capable of effectively reflecting the studied phenomenon. Reliability means whether the sample remains the same in repeated conditions. For example, whether the answers of the same person provided at different times to the same questions are the same. If these points are not heeded, the conclusions can hardly be persuasive and will be questioned. ${ }^{60}$ To

\footnotetext{
58 L. Webley, 'Qualitative Approaches to Empirical Legal Research', supra note 8 , p. 934 .

59 Ibid, pp. 934, 935.

60 Supra note 46 , G. Shaffer, p. 6.
} 
decrease bias, some scholars use findings collected by different methods or from different sources to confirm each other. ${ }^{61}$

\subsection{Multi-method Approach}

Quantitative and qualitative approaches are the two major approaches in ELS. Currently, new legal realism realizes that the relation between the law and society is very complicated, involving individuals, organizations, institutions, social backgrounds and their interactions. It requires comparison and confirmation from different perspectives, diversified levels and aspects, and thus needs to combine multiple methods to facilitate research. In addition, the quantitative approach observes questions such as general distribution and frequency, tending to simplify social problems and overlooking important information. The qualitative approach can only answer questions such as whether something exists, and targets the samples, tending to take a part for the whole. The two approaches have respective limits in collecting and analyzing data and thus need to complement each other. ${ }^{62}$ Consequently, when emphasizing ELS and interdisciplinary research, the new legal realism starts from a position of respecting facts to promoting the multi-method approach in ELS. ${ }^{63}$

Two kinds of multi-method approaches are often used. The first multi-method approach starts with the qualitative method to find a theoretical explanation for the concerned problem through interviews or observations. Then a hypothesis is established for the theory. Next, the quantitative method is used to test the hypothesis, during which process, certain new problems worthy of qualitative research are uncovered. This is called the 'quant sandwich'. The second multi-method approach starts from the quantitative method to test whether an already established general hypothesis can stand. Then, the qualitative method is used to proceed to in-depth analysis according to the tested hypothesis, finding the underlying reasons and variations. Then, a new general hypothesis is

61 C. Seale (ed.), Researching Society and Culture (London: SAGE Publications, 1988) 231.

62 Supra note 53, pp. 953, 955. It discussed the limitations of several particular methods of quantitative approach and qualitative approach, as well as the necessity of combining multi-methods.

63 Supra note13, pp. 843, 849. It discussed the innate limitations of the approaches to empirical legal study and emphasized the need for combining multi-methods according to different situations. 
provided for further quantitative testing. This is called the 'qual sandwich' ${ }^{64}$ Certainly, actual combinations are diversified, the essential point of which is to find suitable methods for the real situations of the researched objects. When looking at different methods, the attitude should be open minded rather than limited or focused on only one method.

\section{DISPUTES OVER AND CRITICISMS OF THE NEW LEGAL REALISM}

The old legal realism entered the stage as a critic. It criticized the self-consistency myth of the legal system advocated by the traditional legalists and proved the existence and function in law and the judiciary of extralegal factors. The new legal realism continued such a role in criticizing the new legal formalism and describing the function of law and judiciary in real life. Its critique certainly met the retort of the new legal formalism, which was directed at the results of the new legal realism, or its research process or methodology. These retorts inspired the self-examination of the new legal realists in responding to them. During these confrontations, the new legal realism and the new formalism constantly reach consensus, discovering the real differences between them. Both have almost the same goal - that of improving the law to better adapt to and advance social development. Certainly, the two have obvious differences in their research routes and value orientation. In fact, there are disputes even within themselves. But because of such friendly confrontation, the two isms push each other forward and develop together.

\subsection{Disputes on the Objects that are Criticized}

Before balanced realism emerged, ${ }^{65}$ the new legal realism had always formulated the main opinions of legal formalism as: believing there exist generally applicable and effective theoretical formulae to resolve all

\footnotetext{
64 Supra note 54, p. 955.

65 The term 'Balanced Realism' was officially put forward by B.Z. Tamanaha in one of his papers. But later B. Leiter wrote a paper saying that the ideas behind this expression had already been described in one of his papers. However, many of the scholars who have quoted this term were referring to B.Z. Tamanaha's paper. Supra note 9, B.Z. Tamanaha, p. 1243; note 9, Brian Leiter, p. 123.
} 
situations within the legal system; and holding that the common law is so self-consistent, broad and logical that judges only need to reason from the existing rules and precedents to decide cases. The new legal realism criticized these opinions and proved that legal theories and rules cannot cover all situations; that not all judgments are reasonable, logical or harmonized; that judgments are not always consistent or reasonably explained by legal rules; and that law is not always predictable. Against these criticisms, the legal formalists revised their original opinions to be: not all situations could be resolved solely through the reasoning of existing rules; ${ }^{66}$ there are gaps in the law, language is vague and the meaning of the language has to be decided in context;67 and judges frequently refer to materials, legislative intention and context besides the legal text to clarify the meaning of the law, needing to make judgments when applying law through other means than mechanical reasoning. ${ }^{68}$ But legal formalism also directed counter-criticism at legal realism, objecting to the use of materials, intentions or contexts outside the legal texts to interpret law without limits, objecting to arbitrarily letting extralegal factors affect judicial decisions, maintaining that law is clear at many times and that its meaning could be clarified through legal reasoning, and holding that too much emphasis on the influence of factors like politics could make the law more uncertain. ${ }^{69}$

Facing these revisions and critics, some new legal realists still held to their previous understanding of legal formalism and criticized its original tenets, which was detrimental to the improvement of research. ${ }^{70}$ Then, B.Z. Tamanaha proposed the idea of balanced realism, arguing that the new legal realists and the new legal formalists had consensus on some

66 A. Scalia, 'Common Law Courts in a Civil Law System: The Role of United States Federal Courts in Interpreting the Constitution and Law', in Antonin Scalia, A Matter of Interpretation: Federal Courts and the Law (New Jersey: Princeton University Press, 1997) 6, 12.

67 Ibid. See F.H. Easterbrook, 'Text, History, and Structure in Statutory Formalism', Harvard Journal of Law and Public Policy (Vol. 17, No. 1, 1999) 67, 68; J.F. Manning, 'Constitutional Structure and Statutory Formalism', University of Chicago Law Review (Vol. 66, Issue 3, 1999) 685.

68 Supra note 67, J.F. Manning, pp. 688, 693; L.B. Solum, 'The Supreme Court in Bondage: Constitutional Stare Decisis, Legal Formalism, and the Future of Unenumerated Rights', University of Pennsylvania Journal of Constitutional Law (Vol. 9, No. 1, 2006) 155, 175.

69 A. Scalia, 'The Rule of Law as a Law of Rules', University of Chicago Law Review (Vol. 56, No. 491989) 1175.

70 R.A. Posner, How Judges Think (New Jersey: Princeton University Press, 2010) 6 . 
aspects. ${ }^{71}$ Although B. Leiter later wrote an article to rebut Tamanaha's opinion that 'legal formalism and legal realism have actually no difference and everyone could be a balanced realist', Leiter still admitted that the two enjoyed some consensus. ${ }^{72}$ Leiter further argued that legal formalism and legal realism do retain some difference, which is mainly a matter of degree. Legal formalists think that judges refer to extralegal factors only when the law is unclear and such situations seldom happen; most times judges are bound by the law. However, legal realists think that even when the law is clear, judges are influenced by extralegal factors, and at most times, when judges are bound, the influencing factors are not only law but also factors like politics. ${ }^{73}$ V. Nourse and G. Shaffer further abstracted such difference, holding that the two varied in believing whether predesigned rational rules exist that could be applicable to all situations through logical reasoning and whether the judges are bound by rules when applying them without considering the results. In a word, whether the rationality is sufficient and whether the judges' sensibility has a role. ${ }^{74}$ According to their definition, Nourse and Shaffer think that the opinions of some legal economists who are often considered legal realists are also legal formalists, because they think that after bringing market institutions and economic analysis into the legal system, the rules could be designed to realize the previous goal of these rules fully binding judges who decide cases simply by logically reasoning from the rules. ${ }^{75}$ However, scholars like Tamanaha think that these legalists also agree that legal rules are not fully consistent and logical and that judges are affected by extralegal factors, and thus consider them as legal realists. ${ }^{76}$ So, there exist different opinions even within legal realism. The new legal realism and the new legal formalism have constantly clarified their understandings and deepened and concretized their discussions on their critiqued objects and maintained positions. During these disputes and criticisms, the new legal realism continuously develops.

71 B.Z. Tamanaha, Beyond the Formalist-Realist Divide: The Role of Politics in Judging (New Jersey: Princeton University Press, 2010) 6.

72 Supra note 9, B. Leiter, p. 123.

73 Supra note 9, B. Leiter, pp. 123, 132.

74 Supra note 20, Victoria Nourse and Gregory Shaffer, pp. 95, 96.

75 Ibid. Victoria Nourse and Gregory Shaffer believe that the representative of the legal economics scholars who are actually the legal formalists is Richard A. Posner.

76 Supra note 9, B.Z. Tamanaha, p. 1263. 


\subsection{The Critics of the Research Methodology}

The 'bottom-up' empirical research method promoted by the new legal realism has attracted many critics. Some are legal formalists and some are legal realists themselves. Some important critiques are that empirical research cannot disclose the underlying reasons for a particular effect, that its results are either too obvious, or meaningless or non-persuasive, and too far from proving the conclusions that they seek to demonstrate, and that they cannot effectively connect 'bottom' with 'up', thus starting from the bottom and ending at the bottom. ${ }^{77}$ These are indeed the deficiencies that ELS finds it hard to overcome.

Facing these critics, empirical researchers have provided several responses; but in practice, such deficiencies are still difficult to overcome. This is because: large-scale data collection is time-consuming and expensive, while scholars have to publish articles within a limited time; the experimental method is not applicable because real society can hardly be imitated in an experiment, for example lawyers and judges attending mock trials know these are mock proceedings and thus would not treat them as true trials; and data collected in reality are normally the results of the influence of several factors, and thus it is difficult to exclude the influence of certain factors to research only one factor.

Apart from the critiques of the objects of research and its methodology, the new legal realism also attracted criticism on other aspects, including its consideration of law as a branch of politics or economics and thus making the error of Reductionism, or believing in the accuracy of current science and so becoming too reliant on science, thus making the Scientism mistake, and so on. ${ }^{78}$ The response of the new legal realism to these critics has been discussed in previous parts of this chapter introducing its recent developments.

\section{INSPIRATION FOR CHINA'S LEGAL RESEARCH}

Although the new legal realism has not formed a legal movement in China, the opinions and methods it promotes are very important for China's current legal studies. Its inspirations are mainly reflected in research attitudes, research methods and the references to existing achievements.

77 Supra note 14, pp. 9, 10.

78 Supra note 20, Victoria Nourse and Gregory Shaffer, pp. 115, 127. 


\subsection{Research Attitude}

When studying the status of the rule of law in China and learning from the experiences of other countries, the actual situations in China should be studied with an objective and neutral attitude, so as to disclose the function of the legal system in our society through the empirical method. When providing suggestions and borrowing from other countries' experience, the attitude should be creative, realistic and critical, and the feasibility of any suggestions should be considered. For example, when learning from American experience in building a case law system, the difference in judicial systems between China and America should be considered, such as the different compositions and forms of the existing rules, the different legal effects of the cases, etc. On the other hand, there are also comparable aspects. When building new case rules in an already existing legal system, it is important to decide what cases are similar in both China and America. ${ }^{79}$

When studying the actual function of law, the research should not end at disclosing the gap between law in books and law in action. It must further analyze this gap, qualify the factors and reasons contributing to the gap, and quantify the influencing routes and degrees of these factors. Upon these analyses and explanations, these factors could be brought into policy-making and legislation to increase the predictability of the actual operation of law and policy. During these research efforts, the boundary between legal and other alternative dispute resolutions could be clarified, and their connection, transmission and cooperation could be strengthened.

The new legal realism also reminds us that in academic exchange, it is important to notice the limits and avoid worship of one's own theory and method, to welcome critics and self-examination and to tolerate opposite opinions. More importantly, scholars of different theories need to find consensus and understand the true differences from which to continue the exchange, rather than wasting time and energy on imagined opponents.

\subsection{Interdisciplinary Research Methodology}

China's interdisciplinary legal research is very limited and elementary. During its development, many of the experiences of the new legal realism are very useful to China in this respect.

79 Deng Jinting, 'Experience of the Construction of the American Case Law System - take Intermediary Contract for Example', Journal of East China University of Politics and Law (No. 2, 2014) 132, 144. 
First, the disciplines that could be brought into legal studies include not only sociology and economics, but also anthropology, politics, and so on. Second, not only the research results but also the models and theories of other disciplines could be borrowed to provide more perspectives. The results could be cited directly and also be translated or utilized indirectly. Regarding the models this chapter has specifically discussed, the results in legal politics should be noted. When studying extralegal factors affecting judicial behavior, one should consider not just one single factor, but also personality, policy, promotion, salary, work pressure, educational background and other factors. When selecting measuring indicators, one should consider not only whether the vote is for or against a certain claim, but also the concrete reasons, the special situations of the case and other indicators. When evaluating the actual effects of a law, one should consider the research results in terms of institutionalism, including the influence of the selected and involved institutions in the realization of the law, their dynamic interactions, the comparison of different institutions in realizing the same law, etc.

Each of the traditional and modern scientific methods has its own values and deficiencies in legal studies and thus they need to complement each other. The theoretical construction and logical reasoning of traditional legal methods have irreplaceable values in proving the unique value of law, understanding the underlying reasons behind surface phenomena and generalizing broadly applicable theory to instruct practice. In contrast, the modern scientific method could contribute to proving the gap between social phenomena and the predictions reasoned out from traditional legal theories, disclosing potential factors that are difficult to foresee in theoretical reasoning, and understanding the actual social situations in play.

The new legal realism promotes a bridging attitude, which is always starting from the problems and facts, and then summarizing the relevant research results in different disciplines through different methods, so as to better understand facts and resolve problems. Concretely speaking, the first goal is to transmit the problems that legal theories want to resolve to other disciplines so that their research has more substantive legal meanings. The second goal is to transmit the research results of other disciplines to legal studies so that such results could be operationalized and reflected in constructing, verifying and evaluating legal systems. The third goal is to promote tolerance of different research methods, increase the cooperation and understanding of their proponents and study facts with a more open-minded attitude. 


\subsection{Inspiration for China's ELS}

The new legal realism also has inspirational effects on China's ELS.

This can be seen firstly in terms of methodology. Many of China's ELS apply only one method - either the qualitative or quantitative approach. They seldom use a multi-method approach and the statistical methods employed are very simple. ${ }^{80}$ But recently there have appeared some ELS in China which use complicated quantitative methods. ${ }^{81}$ The new legal realism inspires us to see that different methods have different applicable scopes, advantages and disadvantages, that it is necessary to constantly update our knowledge in qualitative and quantitative methods, and that it is meaningful to try different methods and compare them. In addition, when observing overall characteristics through samples, China's ELS sometimes have only selected samples from certain places or types and provided predictions of overall situations without considering the representativeness of the samples. Such research has made precisely the mistake objected to by the new legal realism; that is, to make conclusions that a certain phenomenon is very typical and important and thus worthy of attention after having observed only one or two cases and without considering the limits of the samples.

The limitations of each method and the matters that need attention when applying them should be noted. For example, the quantitative method can only resolve questions like frequency and general distribution, and not questions of what and why. Random sampling is required so that the conclusions are reliable. The qualitative approach cannot answer questions like frequency and distribution and recommends purposive samples that are not random but are special and typical, and have a particular span. But the samples need to be collected from multiple channels and perspectives so as to avoid the personal bias of the researchers and to make the conclusions more persuasive. When studying different problems, suitable methods should be applied. When the problem is complicated, the multi-method approach should be considered.

The second field in which the influence of new legal realism can be traced is data collection. Most of China's ELS are based on judgments and are heavily reliant on internal channels and networks. The new and

80 The common statistical analysis technique used in legal quantitative research, supra note 8 , p. 149.

81 It should be seen that there were already Chinese scholars who have delved quite deeply into quantitative research. For example, Wang Zhiyuan, 'State Structure, Competition Politics and Rule of Law - Based on the Data Analysis Study in 1996-2009', Journal of Jurists (No. 2, 2014) 157, 175. 
old legal realism remind us that the limits of data sources and the corresponding data deficiency would obstruct the development of ELS. The recent flourishing of ELS in America is largely due to the establishment of a large amount of databases, especially multi-user databases, and the publication of diversified statistical reports, such as the judicial database of the US Supreme Court and the judicial database of American appellate courts. ${ }^{82}$ China should also vigorously promote the establishment of databases, encourage resource sharing and break the limits of internal data.

The third strand of influence is found in theoretical abstraction. ELS are concerned with bottom-up research, handling legal phenomena within the social context and providing empirical data support for legislation and policy-making. It has beneficial results in predicting changes of law or policy during their implementation. It has to bring out the theoretical meanings of the observed surface phenomena neutrally and objectively. When designing the research and analyzing the data, the 'up' meanings should be considered, and the situations of limited samples need to be reflected objectively and neutrally, even if such a situation does not fit in with the theoretical conclusions.

82 Supra note 13, pp. 829, 831. 